\title{
Abatacept for severe anti-TNF-alfa refractory JIA-associated uveitis: one year follow-up
}

\author{
MG Alpigiani ${ }^{*}$, P Salvati ${ }^{1}$, S Callegari' ${ }^{1}$ A Bagnis ${ }^{2}$, M Papadia $^{2}$, CE Traverso ${ }^{2}$, R Lorini ${ }^{1}$ \\ From 18th Pediatric Rheumatology European Society (PReS) Congress \\ Bruges, Belgium. 14-18 September 2011
}

\section{Introduction}

Uveitis in JIA can be severe and immunosoppressive therapies may not be sufficient. Anti-TNF-alfa agents (Infliximab, Adalimumab) have been proposed. The percentage of success is different among series and no controlled trials have been published yet. Abatacept, a selective T-cell co-stimulation modulator, has been shown to be a valid alternative to anti-TNF-alfa agents in patients with refractory uveitis (Angels-Han S.2008; Zulian 2010).

\section{Case report}

We report on a 20-years-old girl, affected since one year of age, by a severe form of poliarticular JIA. She received immunosuppressors (Metrotrexate, Azathioprine...) associated with steroids, with no articular benefit. When Enbrel plus Metrotrexate was started, she got into remission. After one year she presented uveitis bilaterally, so steroids were started again. She obtained partial ocular improvement, receiving Infliximab plus Metrotrexate, but the former was suspended because of an adverse reaction (dyspnea, rash) and Adalimumab was started, with no side effects. After three years, she had flare for uveitis and arthritis. Adalimumab was suspended and Abatacept was started, with no side effects. After 12 months, uveitis seems to be stable, while arthritis, after a good initial response, seems to be active again.

\section{Conclusions}

In our case, Abatacept was a valid drug in uveitis treatment, less effective in arthritis. In the literature, there are other reports of good response of ocular inflammation, with reduced effectiveness on articular flares

\footnotetext{
* Correspondence: gianninaalpigiani@ospedale-gaslini.ge.it

'Department of Pediatry, Gaslini Institute, Genoa, Italy

Full list of author information is available at the end of the article
}

(Kenawy N., 2011). Long- term follow-up in patients with severe uveitis and JIA treated with Abatacept is necessary to check if this drug is a valid alternative to anti- TNF drugs.

\section{Author details}

'Department of Pediatry, Gaslini Institute, Genoa, Italy. ${ }^{2}$ Eye Clinic, Department of Neurosciences, Ophthalmology and Genetics, University of Genoa, Genoa, Italy.

Published: 14 September 2011

doi:10.1186/1546-0096-9-S1-P189

Cite this article as: Alpigiani et al: Abatacept for severe anti-TNF-alfa refractory JIA-associated uveitis: one year follow-up. Pediatric

Rheumatology 2011 9(Suppl 1):P189.
Submit your next manuscript to BioMed Central and take full advantage of:

- Convenient online submission

- Thorough peer review

- No space constraints or color figure charges

- Immediate publication on acceptance

- Inclusion in PubMed, CAS, Scopus and Google Scholar

- Research which is freely available for redistribution

\section{() Biomed Central}

